\title{
Anne Conway as a Priority Monist: A Reply to Gordon-Roth*
}

\begin{abstract}
For early modern metaphysician Anne Conway, the world comprises creatures. In some sense, Conway is a monist about creatures: all creatures are one. Yet, as Jessica Gordon-Roth (2018) has astutely pointed out, that monism can be understood in very different ways. One might read Conway as an 'existence pluralist': creatures are all composed of the same type of substance, but many substances exist. Alternatively, one might read Conway as an 'existence monist': there is only one created substance. Gordon-Roth has done the scholarship a great favor by illuminating these issues in Conway. However, this article takes issue with Gordon-Roth's further view that Conway 'oscillates' between the extremes of existence pluralism and monism. In its place, I argue we should read Conway as a priority monist: the whole of creation is ontologically prior to its parts.
\end{abstract}

KEYWORDS: Anne Conway, priority monism, pluralism, substance

\section{Introduction}

In the mid-seventeenth century, Anne Conway set out a new metaphysics in her Principles of the Most Ancient and Modern Philosophy. On her system, God's creation comprises 'creatures'. Plants, pebbles, stars, birds, humans-all are creatures. Scholars agree that in some sense Conway is a monist about creatures: all creatures are one. Yet, as Jessica Gordon-Roth (20I8) has insightfully pointed out, scholars can understand that monism in very different ways.

Uncontroversially, Conway is a monist about the type of creatures that exist: all creatures are the same type of substance. But this leaves open a further question. If there is just one type of created substance, how many tokens does it have? Is each creature an individual created substance, or is there only one created substance? With regard to creatures, some scholars have assumed that Conway is an 'existence pluralist': many created substances exist. Other scholars have assumed that Conway is an 'existence monist': there is only one created substance. GordonRoth has successfully shown there is an invisible debate going on in the scholarship around this issue, wherein scholars are making assumptions about Conway rather than offering arguments, unaware they are even disagreeing with

\footnotetext{
* This article is the sixth in a special series of commissioned articles on women in the history of philosophy. The fifth article 'Martha Kneale on Why Metaphysical Necessities Are Not A Priori', by Jessica Leech, appeared in Volume 5, Issue 4, pp. 389-409.

I am grateful to Jeremy Dunham and two anonymous referees for this journal for helpful comments on earlier drafts of this article.
} 
each other. Gordon-Roth has significantly advanced the literature by bringing this previously unrecognized debate to the surface.

Is Conway an existence pluralist, or an existence monist? Gordon-Roth claims that Conway 'oscillates' between the extremes of existence pluralism and monism, and it is this claim that I take issue with. Although I agree with Gordon-Roth that there is both pluralism and monism in Conway's ontology of creation, I argue the oscillating reading lacks motivation. This article advances a new reading altogether: Conway is a priority monist, holding that the whole of creation is prior to its parts. I argue this reading makes best sense of the passages in the Principles leaning toward existence pluralism and monism.

\section{Existence Pluralism or Monism in Conway's Principles?}

\section{I.I Contrary passages within the Principles}

The Principles repeatedly claims that creatures have parts which are themselves creatures. For example, Conway (III. 5) writes, 'every creature, no matter how small . . . has in itself such an infinity of parts or rather of entire creatures that they cannot be counted'. Clearly, there are many creatures. Are there also many created substances?

As Gordon-Roth (2018: 286) explains, in several passages Conway uses the term 'creature' or 'body' interchangeably with 'substance'. For example, Conway (IX.8) writes that 'shape and life coexist exceedingly well in one substance or body [substantia vel corpore]'. Conway also refers to created substances, plural:

[E]very motion and action, considered in the abstract, has a marvellous subtlety or spirituality in itself beyond all created substances [substantias creatas] whatsoever . . . yet motion and action are nothing but modes of created substances [modi substantiarum creatarum]. (IX.9)

These passages and others have led several scholars to assume, without argument, that Conway holds existence pluralism about created substance. As Gordon-Roth (2018: 288-89) details, this reading can be found, for example, in Peter Loptson (I982: I 5), Jacqueline Broad (2002: 70), and my previous work (2018: I40-4 I).

Confusingly, other passages in the Principles appear to support existence monism about created substance. Gordon-Roth (201 8: 287) collects a few of these passages together. Going beyond Gordon-Roth, I argue the existence monism reading is most forcefully advanced by considering what Conway does and does not say about real distinctions.

The Principles states there are three species: God, Christ, and creatures. Conway (VI.4) asserts that these species are 'really distinct' from each other 'in terms of their substance or essence'. The notion of a 'real distinction' is prominent in Descartes, who claimed that a real distinction only holds between two or more substances (CSM I 2I3-I5). Henry More, Conway's one-time tutor and close friend, also

\footnotetext{
${ }^{\text {I }}$ All quotations from the Principles given in English, unless otherwise noted, are as found in the I996 Corse and Coudert translation. The words, phrases, and passages I provide in Latin are from the 1982 edition by Peter Loptson; the Latin text is the closest we have to Conway's original English text, which was lost.
} 
claimed that 'real' distinctions hold between substances; see More (I995, I 26-8). We know that Conway read the work of Descartes and More very closely, and she appears to use this distinction in the same way. (On Conway's relationship with More, and her studies, see Hutton's 2004 intellectual biography.)

Conway (VI.5) criticizes those who hold that God and creation together are 'one substance', confusing God with his creatures; this may be a reference to Spinozism. On her own system, Conway (V.3) insists that 'the nature of creatures is really distinct from the nature of God' (my emphasis). Conway is stressing a difference between herself and the likes of Spinoza: for Conway, God and creatures are 'really distinct' substances.

In several places, Conway is explicit that there is a real distinction between creatures, Christ and God. In Principles VI.4 she makes this claim and then, in the same section, goes on to discuss distinctions between creatures. Importantly, Conway does not tell us that a real distinction holds between creatures. She writes that creatures are distinguished from each other 'modally':

just as God is one and does not have two or three or more distinct substances in himself . . . so likewise all creatures, or the whole of creation, are also a single species in substance or essence, although it includes many individuals gathered into subordinate species and distinguished from each other modally but not substantially or essentially ... God has implanted a certain universal sympathy and mutual love into his creatures so that they are all members of one body [membra sunt unius corporis] . . for whom there is one common Father, namely, God in Christ or the word incarnate. There is also one mother, that unique substance or entity from which all things have come forth, and of which they are the real parts and members [unica nimirum illa substantia, sive, entitas, ex qua prodierunt, cujusque reales partes sunt \& membra]. (VI.4)

The strong implication is that, within creation, individuals are not really distinct from one another. If there are no real distinctions between creatures, then seemingly creatures are not substances. To my mind, this provides the strongest evidence for reading Conway as an existence monist about created substance.

This monist reading is seemingly confirmed in additional passages such as these:

$[\mathrm{C}]$ reation is one entity or substance in respect to its nature or essence. (VII.I)

[T] here is also a certain universal love in all creatures for each other. . . all things are one in virtue of their primary substance or essence and are like parts or members of the same body. (VII.3)

[T]he whole creation is always just one substance or entity. (VII.4)

Such passages likely explain why some scholars have assumed that Conway is an existence monist. As Gordon-Roth (2018: 288) shows, this reading is present in Sarah Hutton (2004: 3) and Christia Mercer (20I2: I 85 ). 
In the face of these contrary passages, how should scholars interpret Conway's account of creation? Assuming charitably that Conway is consistent within the Principles, a single text, one strategy is to maintain that Conway is an existence pluralist or monist about created substance, and account for apparently conflicting passages. Another strategy is to find an alternative reading, between these extremes. Gordon-Roth does exactly that.

\section{I.2 Is Conway Oscillating between Existence Monism and Pluralism?}

On Gordon-Roth's reading, Conway is neither an existence pluralist nor an existence monist. If asked 'How many spiritual substances are there in creation?', GordonRoth claims that Conway would 'oscillate' between two different answers. From the perspective of God, there is one spiritual substance in creation; from the perspective of creatures, there are many.

There is no textual evidence directly supporting this reading. However, as Gordon-Roth (2018: 292-93) rightly points out, there is textual evidence showing that Conway oscillates on other questions about creation. For example, she considers the question 'Did the act of creation happen all at once, or successively?'. Conway writes that God and creatures answer this question differently:

[I]f the word 'to create' refers to God himself or to an internal decree of his will, then creation occurred all at one time. But if 'to create' refers to creatures, then it occurred successively over time. (IV.I)

Gordon-Roth also considers the question 'Can we count the number of creatures?'. Conway (VII.4) writes that for a creature the number is 'countless', as they cannot 'enumerate' the infinity of creatures. In contrast, God 'perfectly knows' the number of creatures.

As Conway oscillates on these questions, Gordon-Roth argues she may also oscillate on our question, too:

[For Conway] the question, 'How many spiritual substances are there in creation?' might not have a singular answer . . . it may be that because God is outside of time, and thus 'sees' all at once, it appears as if there is just one dynamic thing that is creation. Thus, what seem to be individual spiritual substances to creatures (situated in time) are better described as parts or aspects of the one vital and spiritual substance that is creation from God's perspective ...

Conway oscillates ... and this depends upon whether she is referring to God or creatures as she describes things. (Gordon-Roth 201 8: 293)

To render this reading plausible, Gordon-Roth must explain why God and creatures would answer this question differently.

On the two cases of 'oscillating' explicitly given in the Principles, it is easy to see why God and creatures would answer the same questions differently. God and 
creatures stand in different relations to time, so it is understandable that for God creation happens all at once, whereas for creatures it occurs successively over time. Similarly, creatures' finite minds cannot compute infinities so it is understandable they cannot count infinite things, whereas God's infinite mind can. In both cases, there are straightforward differences between God and creatures that explain why they would answer the same question differently.

In contrast, it is hard to see why God and creatures might provide different answers to the question 'How many spiritual substances are there in creation?'. Gordon-Roth suggests it is because of their relations to time. Creatures 'situated in time' perceive many substances. In contrast, God perceives one substance 'because God is outside of time'. I discuss each part of this reasoning in turn.

Gordon-Roth claims that, unlike God, creatures 'situated in time' perceive many substances. She implies there is something about our existence in time that makes us see multiplicity. What might that be? Gordon-Roth does not spell out her reasoning, but plausibly she is thinking of Conway's explicit thesis that creatures' existence over time is successive, whereas God's timeless existence is not. Our existence is successive in that we experience things happening after other things. When we listen to music, one musical note is succeeded by another such that we hear each note individually, and do not hear them all at once. One might think that the successive nature of our experience leads us to perceive multiplicity. Perhaps experiencing things happening after other things leads creatures to divide those things up into individuals, rather than conceiving things to be aspects of one individual.

Although it is possible that our existence in time leads us to perceive multiplicity in this way, I am doubtful. Here is a thought experiment to motivate that doubt. Imagine watching a street from a doorway. At midday a tan spaniel strolls past, at one o'clock a sooty spaniel strolls past, and at two o'clock a muddy spaniel strolls past. It is possible you saw three different dogs, at three different times. It is also possible you saw numerically one dog changing over time, as a tan spaniel covered itself in soot, and later covered itself in mud. Because we saw the dogs successively, are we more likely to conclude we saw three different dogs? I do not believe so. You might leap to the conclusion you saw three different dogs, or to the conclusion that you saw the same dog getting mucky in different ways.

Thought experiments aside, perhaps the advocate of the oscillating reading would argue that creatures such as ourselves clearly do perceive the world to be many, given the popularity of pluralism among contemporary philosophers and the unpopularity of monism. As Jonathan Schaffer (2016) notes, monism is not 'accorded much respect in contemporary metaphysics', its tradition long 'dismissed as being somewhere between obscure and ridiculous'. Perhaps the advocate of the oscillating reading could cite the likes of Bertrand Russell, who claimed in I9I 8 that the belief 'there are many separate things' is commonsensical (Russell I988: I78). Of course, not everyone finds pluralism commonsensical. In response to Wittgenstein and Russell, Bland Blanshard (I9I9: I79-80) argued for what he called the intuitive conviction of the 'plain man', that the world forms a closely knit unity, and is not a 'rag-bag of loose ends'. If there is something about creatures' existence in time that leads them to perceive multiplicity, it is not obvious. 
Gordon-Roth claims that because a timeless God 'sees' everything all at once, it appears as if there is just one dynamic thing that is creation. I find it difficult to motivate this claim. On Judeo-Christian theology, eternity is an attribute of God. Divine eternity can be understood in different ways but, historically, God's eternity was widely understood to be timeless. This is the tradition Conway is working within. It stretches back at least to Augustine, Boethius, and Aquinas (see Deng 2018: $\$ 3$ for an historical overview). Divine timelessness raises many theological and philosophic issues but, as far as I am aware, it has never been suggested that a timeless God would perceive creation monistically. There is no obvious link between divine timelessness and a monistic perspective on creation and the link is not, for example, found in monographs on divine timelessness by Brian Leftow (I99I), Alan Padgett (I992), William Craig Lane (200I), Paul Helm (20II), or Natalja Deng (20I9). In the absence of further argument on behalf of the oscillating view, we should not accept that there is something about the timelessness of Conway's God that leads him to conceive creation as one substance.

On the two explicit cases of 'oscillating' that Gordon-Roth finds in Conway's Principles, it is easy to see why the same question is answered differently by God and creatures. However, when we move to the question 'How many spiritual substances are there in creation?' it is not easy to see why this would be answered differently by God and creatures. Gordon-Roth suggests it is because creatures in time perceive many substances, whilst a timeless God perceives one substance. In the absence of textual support from Conway's Principles or additional argument, this reading lacks plausibility. It is unclear why creatures' successive existence in time would lead them to perceive creation pluralistically, or why divine timelessness should be linked to a monistic perspective on creation.

\section{Conway as a Priority Monist}

I agree with Gordon-Roth that Conway is neither an existence monist nor an existence pluralist. However, I defend a different middle road between these positions: I argue Conway is a 'priority monist'.

'Priority monism' has been defended relatively recently by Jonathan Schaffer, and it incorporates two ingredients. The first ingredient is the thesis that ontological priority relations-and their inverse, ontological dependence relations-hold between things. Jonathan Schaffer (2010b: 345) defines ontological dependence as the 'metaphysical notion on which one entity depends on another for its nature and existence'. For example, you might think that the property greenness ontologically depends on the particular that bears it: if a leaf ceases to exist, its greenness ceases to exist also. Similarly, frowns seem to ontologically depend on faces. (For further discussion see Fine I995: 269; Schaffer 20I0a; Tahko and Lowe 2016: \$3).

The second ingredient is the thesis that the cosmos is a mereological whole, and everything that exists is a proper part of it. Schaffer (2010a: 33-34) compares the cosmos to a cat. He argues there is structure to a cat: the nose is part of the head but not part of the paws. If you noted the existence of the cat, and its nose, head, and paws, but missed the part-whole relations between them, you would have 
missed an aspect of the cat. Schaffer makes the same claim of the world: if you listed what things exist, but missed the part-whole relations between them, you would have missed an aspect of the world.

Priority monism puts these ingredients together. Priority monists argue wholes are ontologically prior to parts, and parts are ontologically dependent on wholes. Schaffer (20I0a: 47) points to 'integrated wholes' such as syllables, circles, and organisms, and he argues that commonsense recognizes that they are prior to their parts. He finds historical support for this view: 'Aristotle gives the right angle and the acute angle, and the man and his finger, as examples in which the whole is prior to part'. Priority monists further claim that the universe is an integrated whole, and so the universe is prior to its parts. This is a form of monism: the one universe is prior to its many parts. The one universe is ontologically fundamental, and its many parts derivative. As Schaffer (2010a: 33) puts it, 'the world has parts, but the parts are dependent fragments of an integrated whole'. Schaffer (20I6: $\$ 3$.I.I) claims that priority monism may have been defended in various forms by Plato, Plotinus, Proclus, Spinoza, Hegel, and F. H. Bradley.

Priority monism agrees with existence pluralism that many things exist. However, priority monism agrees with existence monism that the universe is, in an important sense, one. I argue that reading Conway on creation as a priority monist makes sense of the seemingly contradictory passages in the Principles.

The two ingredients of priority monism are both present in Conway. The first ingredient-that ontological dependence and priority relations hold between things-abounds in early modern metaphysics. For example, Descartes writes,

By substance we can understand nothing other than a thing which exists in such a way as to depend on no other thing for its existence. And there is only one substance which can be understood to depend on no other thing whatsoever, namely God. (CSM I 2 IO)

God is ontologically prior to created substances, for all created substances depend on God for their existence. In his Cogitata Metaphysica Spinoza (II:3) agrees, and he actually uses this to mount an argument for divine omnipresence: 'we prove that God is everywhere present . . . [because] nothing could exist even for a single moment unless procreated continually by the power of God'. Like her peers, Conway also uses these notions. Conway (I.7) tells us creatures depend on God: 'creatures have their essence and existence purely from him because God . . . wishes them to exist'. Conway lists God's 'incommunicable' attributes, attributes that God possesses yet creatures do not. Alongside 'infinite' and 'most perfect', she includes 'independent'. God does not depend on anything else for his existence, whereas everything else depends on God.

The second ingredient is not widely found in early modern metaphysics, but it is in Conway's. As we saw above, she is explicit that creation is a unique substance of which all things are 'real parts'.

Are there any reasons to believe Conway puts these two ingredients together into a priority monist account of creation? I argue so. One reason is that a few passages in the Principles suggest that the whole of creation is prior to its parts. Above, Conway 
claimed not merely that all things are 'real parts' of created substance but that this is the entity 'from which all things have come forth'. This suggests that the whole of created substance is prior to its real parts. In addition, one of Conway's descriptions of creation implies that earth and water are wholes, prior to the smaller creatures that are their parts:

[D]oes not rotting matter, or body of earth and water, produce animals without any previous seed of those animals? And in the creation of this world did not the waters produce fish and birds at God's command? Did the earth not also at the same command bring forth reptiles and beasts, which were, on this account, real parts of earth and water? [Nonne etiam terra ad idem mandatum proferebat reptilia atque bestias, quae propterea reales erant terrae et aquae partes?]. (VI.6)

The earth brings forth creatures that are real parts of it.

Another reason is that Conway repeatedly compares the parts of the universe to the parts of a living body, an idea indicative of priority monism. The notion that a living body is prior to its parts dates to Aristotle. 'Some things are called prior and posterior', Aristotle writes in Metaphysics V.I I, IoI9a2, 'in respect of nature and substance, i.e. those which can be without other things, while the others cannot be without them' (I995b). Further on (VII.ro, I034b30), Aristotle adds that in a unity such as a living organism, the whole is prior to the parts, and this is why a man is prior to his fingers. Although whole organisms are prior to their parts, in Categories 3a29-32, Aristotle maintains that their parts are substances-that the parts of substances are substances (I995a). This makes sense, for the parts of substances are able to fulfil a key criterion of substancehood: they can support properties or modes. A finger can be straight or crooked, slim or pudgy.

Reading Conway as a priority monist would explain the passages within the Principles that seem to lean toward existence pluralism, and those that seem to lean toward existence monism. Priority monism is consistent with the passages in Conway implying that creatures are substances, and that there are many created substances. It is also consistent with Conway's claim that the whole of creation is a single substance or entity. Fundamentally, creation is one substance-it just happens to have parts that are also substances. This would explain Conway's statement that creation is a unique substance or entity from which all things have come forth, and of which they are real parts and members. It would also explain why there is no real distinction between the parts of creation. For a real distinction to hold between the parts of creation, those parts must be able to exist independently of each other. Yet they do not exist independently of each other: the parts of creation ontologically depend upon creation as a whole.

\section{Conclusion}

Is Conway an existence monist or a pluralist about created substance? In raising this question, Gordon-Roth has identified an important murkiness in the scholarship, and a debate that was previously swimming out of sight. Gordon-Roth is right to 
highlight both the pluralism and the monism in Conway's system, and I agree with her that Conway is not straightforwardly an existence monist or an existence pluralist.

Part of what makes Gordon-Roth's article valuable is that it will spark further debate over this issue in Conway. In that spirit, I advance an alternative reading of the Principles on creation. On the oscillating reading, the seemingly conflicting passages within Conway's Principles are reconciled by arguing that God and creatures provide different answers as to how many substances there are. To my mind, this reading lacks textual evidence, and requires further argument as to why God and creatures perceive creation differently. In contrast, on the priority monism reading, the seemingly conflicting passages are reconciled by arguing that Conway is a priority monist. In answering how many created substances are there, there is no need for Conway to oscillate between the perspectives of God and creatures. There is simply one created substance, and it is prior to its many parts. I argue this reading makes best sense of the passages that apparently lean toward existence monism, and toward existence pluralism. We should read Conway as a priority monist.

EMILY THOMAS

DURHAM UNIVERSITY emily.e.thomas@durham.ac.uk

\section{References}

Aristotle. (I995a) Categories. In Jonathan Barnes (ed.), The Complete Works of Aristotle: The Revised Oxford Translation, vol. I (Princeton, NJ: Princeton University Press), 3-24.

Aristotle. (1995b) Metaphysics. In Jonathan Barnes (ed.), The Complete Works of Aristotle: The Revised Oxford Translation, vol. 2 (Princeton, NJ: Princeton University Press), I $552-1728$.

Blanshard, Bland. (1919) Reason and Analysis. La Salle, IL: Open Court.

Broad, Jacqueline. (2002) Women Philosophers of the Seventeenth Century. Cambridge: Cambridge University Press.

Conway, Anne. (1982) The Principles of the Most Ancient and Modern Philosophy. Edited by Peter Loptson. The Hague: Martinus Nijhoff.

Conway, Anne. (1996) The Principles of the Most Ancient and Modern Philosophy. Translated by Taylor Corse and Allison Coudert. Cambridge: Cambridge University Press.

Deng, Natalja. (20I 8) 'Eternity in Christian Thought'. In Edward N. Zalta (ed.), The Stanford Encyclopedia of Philosophy (Fall 2018 edition). https://plato.stanford.edu/archives/fall2OI 8/ entries/eternity/.

Deng, Natalja. (2019) God and Time. Cambridge: Cambridge University Press.

Descartes, René. (1985) The Philosophical Writings of Descartes. Translated by John Cottingham, Robert Stoothoff, and Dugald Murdoch. 2 vols. Cambridge: Cambridge University Press. [CSM]

Fine, Kit. (1995) 'Ontological Dependence'. Proceedings of the Aristotelian Society, 95, 269-90.

Gordon-Roth, Jessica. (2018) 'What Kind of Monist is Anne Finch Conway?' Journal of the American Philosophical Association, 4, 280-97.

Helm, Paul. (20I I) Eternal God: A Study of God without Time. Oxford: Oxford University Press. Hutton, Sarah. (2004) Anne Conway: A Woman Philosopher. Cambridge: Cambridge University Press.

Lane, William Craig. (200I) Time and Eternity: Exploring God's Relationship to Time. Wheaton, IL: Crossway Books.

Leftow, Brian. (1991) Time and Eternity. New York: Cornell University Press. 
Loptson, Peter. (1982) 'Introduction'. In Peter Loptson (ed.), The Principles of the Most Ancient and Modern Philosophy, by Anne Conway (The Hague: Martinus Nijhoff), I-6o.

Mercer, Christia. (2OI2) 'Knowledge and Suffering in Early Modern Philosophy: G. W. Leibniz and Anne Conway'. In Sabrina Ebbersmeyer (ed.), Emotional Minds (Berlin: De Gruyter), I79-206. More, Henry. (I995) Henry More's Manual of Metaphysics: A Translation of the Enchiridium Metaphysicum (1679). Translated by Alexander Jacob. 2 vols. Hildesheim: Georg Olms Verlag.

Padgett, Alan G. (I992) God, Eternity and the Nature of Time. London: Macmillan.

Russell, Bertrand. (I988) Logic and Knowledge: Essays I90 I-I950. London: Routledge.

Schaffer, Jonathan. (20I0a) 'Monism: The Priority of the Whole', Philosophical Review, I I 9, 3 I-76.

Schaffer, Jonathan. (20IOb) 'The Internal Relatedness of All Things', Mind, I I9, 34I-78.

Schaffer, Jonathan. (2016) 'Monism'. In Edward N. Zalta (ed.), The Stanford Encyclopedia of Philosophy (Winter 2016 edition). https://plato.stanford.edu/archives/winzor 6/entries/monism/. Spinoza, Benedictus. (1974) The Principles of Descartes' Philosophy. La Salle, IL: Open Court.

Tahko, Tuomas E., and E. Jonathan Lowe. (20I6) 'Ontological Dependence'. In Edward N. Zalta (ed.), The Stanford Encyclopedia of Philosophy (Winter 2016 edition). https://plato.stanford. edu/archives/winzor 6/entries/dependence-ontological/.

Thomas, Emily. (2018) 'Anne Conway on the Identity of Creatures over Time'. In Emily Thomas (ed.), Early Modern Women on Metaphysics (Cambridge: Cambridge University Press), I 3 I-49. 